\title{
Hur bedömer socialarbetare socialbidragstagares försörjningshinder?
}

\author{
JENNY NYBOM
}

I artikeln studeras socialarbetares bedömningar av socialbidragstagares försörjningshinder utifrän dimensionerna moral, resurs och marknad. Uppgifter frain socialarbetare ifyra kommuner om sammanlagt 372 klienter analyseras. Resultaten visar att klienternas resurser har framträdande plats i bedömningarna. Försörjningshinder i gränslandet mellan moral och resurs tar socialarbetarna ofta upp hos ungdomar men sällan hos utrikes födda bidragstagare.

Hur bedömer socialarbetare socialbidragstagare? I forskningssammanhang har den frågan främst behandlats som prövningen av rätten till socialbidrag. Den har då oftast studerats genom vinjettstudier där socialarbetare hypotetiskt beviljar eller avslår en bidragsansökan utifrån en beskrivning av några typiska klientförhållanden. Resultaten visar att socialarbetares åsikter om rätten till bistånd och storlek på berättigat bistånd varierar till synes godtyckligt

Jenny Nybom, fil.mag i sociologi, forskningsassistent, institutet för utveckling av metoder i socialt arbete (IMS), Socialstyrelsen. Doktorand, institutionen för socialt arbete, Stockholms universitet.
(Gustafsson et al. 1990, Hydén et al. 1995, Stranz 2007). Men bedömningen av hjälpsökande omfattar inte bara prövningen av rätten till bistånd. Forskning om fattigvården, sedermera socialtjänsten, visar att hjälpsökandes hinder att försörja sig genom arbete, vidare benämnt försörjningshinder, har varit en central fråga i hanteringen av berättigade klienter (Midré 1990). Det kan kopplas till fattigvårdens och socialbidragshanteringens delvis motstridiga uppgifter; att garantera och kontrollera att endast personer som inte själva kan tillgodose sina behov får ekonomiskt stöd och samtidigt bistå och kontrollera berättigade klienters försök att bli självförsörjande. Socialarbeta- 
res bedömning av om en klient har försörjningshinder, och vilka, är därför ständigt aktuell för såväl kontroll som stödjande insatser i socialbidragsärenden. Trots det saknas i stor utsträckning systematisk kunskap kring bedömningar av försörjningshinder.

En utgångspunkt i artikeln är att socialarbetares bedömningar av försörjningshinder inte kan ses som objektiv information om klienten och att det därför är viktigt att analysera hur bedömningarna varierar. Det begreppsliga verktyget för en sådan analys hämtas i nordisk forskning om den institutionaliserade synen på hjälpsökande. Med den institutionaliserade synen på hjälpsökanden menas de tankegångar om hjälpsökande och orsaker till hjälpbehov som uttrycks i socialpolitiska lagar och styrdokument. Forskningen visar att den institutionaliserade synen på hjälpsökande innehåller tre dimensioner som framhålls olika mycket under olika strukturella förhållanden. Dimensionerna benämns moral, resurs och marknad och handlar om de hjälpsökandes moral, de hjälpsökandes resurser respektive samhällets ansvar för enskildas möjlighet att få arbete (Midré 1990). Artikelns syfte är att analysera socialarbetares bedömningar av socialbidragstagares försörjningshinder utifrån dessa dimensioner. Ett delsyfte är att beskriva aktuella institutionella och strukturella förhållanden som berör hjälpsökande och diskutera variationer i socialarbetarnas bedömningar i relation till dessa. Följande frågor undersöks i artikeln:

- Vilka försörjningshinder tar socialarbetare upp för klienterna - är försörj- ningshinder inom moral-, resurs-, eller marknadsdimensionen vanligast?

- Vilka försörjningshinder tar socialarbetare upp för olika klientgrupper förekommer försörjningshinder inom moral-, resurs-, och marknadsdimensionen i olika utsträckning för olika grupper?

- Vilka försörjningshinder förekommer ofta samtidigt hos klienterna enligt socialarbetarnas uppfattningar?

Analysen bygger på tvärsnittsdata om socialarbetares bedömningar av sina klienters försörjningshinder. Orsaksförhållandet mellan socialarbetares bedömningar och institutionella och strukturella förändringar undersöks inte eftersom data inte belyser förändringen $i$ denna relation över tid.

\section{Socialarbetares bedömningar och den institutionaliserade synen på hjälpsökande}

Ur ett klientperspektiv är det viktigt hur bedömningen av försörjningshinder går till eftersom den kan antas ligga till grund för det stöd klienten får eller inte får. $\mathrm{Om}$ bedömningar systematiskt fokuserar eller ignorerar vissa försörjningshinder för vissa klienter kan det ha betydelse för klientens möjligheter till rätt stöd. Av befintlig forskning kan man dra slutsatsen att bedömningar av klienterna inte kan ses som objektiv information om klienterna. Det illustreras bland annat av studier där klient och socialarbetare har olika uppfattning om klientens förhållanden och orsaker till biståndsbehovet (se t. ex. Bergmark 1991, 
Nybom et al. 2005). Det illustreras också av studier om samtal och möten i socialbidragsärenden som visar att socialarbetares subjektiva föreställningar om klientens (arbets-)moral är ett påtagligt inslag i deras bemötande och hantering av olika klienter (Hydén 1991, Gunnarsson 1993, Kullberg 1994, Billquist 1999). Mot denna bakgrund är variationer i socialarbetarnas bedömningar av försörjningshinder ett relevant undersökningsobjekt. Frågan är hur vi fångar in variationer i bedömningar av försörjningshinder på ett meningsfullt sätt.

Socialtjänstlagen och andra socialpolitiska styrdokument utgör socialtjänstens "institutionella ordning" (Midré 1990). De har syftet att reglera hanteringen av hjälpsökande och det är därför rimligt att utgå ifrån att den institutionaliserade synen på hjälpsökande kan ha betydelse för socialarbetarnas bedömningar. Midrés (1990) analys av den norska fattigvården/socialtjänsten som institution från 1600/1700talet och framåt visar att dimensionerna moral, resurs och marknad omväxlande varit framträdande i lagtexter och andra socialpolitiska dokument under olika samhällsförhållanden. Senare forskning har visat på dimensionernas giltighet $i$ analyser av den svenska fattigvårdsinstitutionen (Gunnarsson 1993, Bergmark 1993, Lindqvist \& Marklund 1995, Wallentin 1999, Junestav 2004). Följande beskrivning av dimensionerna och deras koppling till strukturella förhållanden bygger på Midrés (1990) studie.

Moraldimensionen betecknas av tankegångar som förlägger ansvaret för bidragsbehovet på individen genom att, uttalat eller outtalat, ifrågasätta de hjälpsökandes arbetsmoral och arbetsvilja. Moraldimensionen var tydlig under 1600- 1700- och 1800-talet. Då antogs lösdrivare (arbetslösa) och ogifta mödrar ha bristande moral, vara lata och liderliga. Arbetsmoralen ifràgasattes implicit i resonemang om att hjälpsökande skulle fostras till högre arbetsmoral genom tvångsarbete i tukthus och arbetshus. Enligt Midré har moraldimensionen gått hand i hand med höga krav på klienten att visa sig arbetsvillig och den har varit framträdande vid arbetskraftsunderskott i samhället då produktionen varit i behov av arbetskraft.

Resursdimensionen representeras av socialpolitiska resonemang om hjälpsökandes resursbrister. Den rymmer en acceptans av att (för tiden) legitima resursbrister innebär att hjälpsökande inte kan försörja sig genom arbete. På 1900-talet uppmärksammades hjälpsökandes brist på resurser alltmer i det offentliga tänkandet och den enskildes moraliska ansvar tonades ned. Sjukdomsbegreppet utvidgades och hjälpsökande som tidigare hade betecknats med moraliserande omdömen beskrevs istället med medicinska termer som "sociopat" och "psykopat«. Under 1950-, 1960- och 1970talen började resursbrister betraktas som påverkbara. Ett rehabiliterings- och omskolningsperspektiv utifrån rätten till arbete snarare än skyldigheten att arbeta blev framträdande i socialpolitiken. De sysslor som hjälpsökande utförde för att få bidrag diskuterades som behandling och inte som fostran till arbetsvillighet. Midré menar att resursdimensionen framhållits när det funnits ett överskott på arbetskraft i samhället och arbetsgivare kunnat välja bort personer med begränsad arbetsförmåga. 
Marknadsdimensionen kännetecknas av tankegångar som förlägger ansvaret för att människor skall kunna få arbete på samhället och inte på individen. I offentliga resonemang var frågor om arbetsmarknadens utbud och statens möjligheter att påverka detta framträdande under 1970och 80-talens expansionistiska period då arbetsmarknadspolitiken byggdes ut för att mildra arbetslöshetens konsekvenser för medborgarna. Midré menar att när marknadsdimensionens betydelse betonas i socialpolitiken så stärks kraven på att det offentliga skall bistå hjälpsökande eftersom individens socialbidragsbehov i högre grad betraktas som oförskyllt.

Dimensionerna i den institutionaliserade synen på hjälpsökande bildar ramen för att analysera socialarbetarnas bedömningar av olika klienters försörjningshinder. Ett allmänt antagande är dock att socialarbetare, i egenskap av professionella i en så kallad gräsrotsbyråkrati, inte tillämpar eller återspeglar den institutionella ordning de verkar inom på något mekaniskt eller entydigt sätt. Nyinstitutionellt inriktade organisationsteorier och studier visar att glappet mellan det praktiska arbetet i en gräsrotsbyråkrati och dess institutionella form ibland kan vara stort. En etablerad utgångspunkt i denna forskning är att socialarbetare har en relativt stor handlingsfrihet när det gäller att omsätta, omtolka eller till och med koppla sig loss från socialpolitiska mål och styrinstrument (Prottas 1979, Lipsky 1980, Johansson 1992, Ahrne 1993, Johansson 2001). Socialarbetare har alltså möjligheten att acceptera eller motsätta sig de synsätt på hjälpsökande som socialpolitiska styrdokument ger uttryck för.

\section{Institution, arbetsmarknad och hjälpsökande idag}

Sedan 1990-talet har moraldimensionen fått ett tilltagande utrymme i lagar och styrdokument kring hjälpsökande i norden och Europa. Den slutsatsen dras i flera svenska och internationella studier som visar att hjälpsökandes skyldighet till motprestationer för att behålla rätten till socialbidrag blivit allt mer uttalad under perioden (Lødemel \& Trickey 2001, Johansson 2001, Giertz 2004, Ulmestig 2007). Som exempel på den här utvecklingen i Sverige anges ofta lagändringen 1998 som ger socialtjänsten möjlighet att neka bistånd till hjälpsökande som inte vill delta i praktik eller annan kompetenshöjande verksamhet. Om den hjälpsökande är under 25 år gäller detta oinskränkt och utan krav på någon bedömning av om ungdomen är i behov av kompetenshöjande insatser. För personer över 25 år kan socialtjänsten neka bistånd på samma grunder om klienten bedöms »av särskilda skäl vara i behov av kompetenshöjande insatser" (6d § SoL, 4 kap. 4-6 § SoL). Kraven på motprestationer har alltså varit särskilt uttalade kring ungdomar (personer under 25 år).

Samtidigt tyder aktuella svenska studier på att staten (arbetsförmedlingarna) alltmer undandragit sig ansvaret att ge arbetsmarknadsinsatser till personer som har socialbidrag som försörjning (SOU 2000:3, Ulmestig 2007, SOU 2007:2). Det innebär att socialbidragstagares motprestationer för att få socialbidrag, i högre grad än tidigare, sker genom deltagande $i$ kommunala och inte statliga aktiveringsinsatser för arbetslösa. Studier om kom- 
munal aktivering visar att den i likhet med prövningsprocessen har godtyckliga inslag. Socialbidragstagare hänvisas till aktiveringsprogram med påfallande varierat innehåll utan att systematiska bedömningar av deras behov eller försörjningshinder har gjorts (Socialstyrelsen 2004, Hedblom 2004, Salonen \& Ulmestig 2004, Thorén 2005, Blomberg et al. 2006). Denna till synes godtyckliga hantering av klienterna, i kombination med socialtjänstens utökade möjligheter att neka socialbidrag till klienter som inte deltar i aktiviteter, har fått forskare att dra paralleller till gamla tiders fattigvårdsinstitution där moraldimensionen var påtaglig (se t. ex. Giertz 2004, Ulmestig 2007).

Parallellt pågår strukturella förändringar på arbetsmarknaden som snarare borde innebära att klienternas resurser, rehabilitering och omskolning framhölls i det socialpolitiska tänkandet. Förenklat var det tidigare så att många människor med få problem behövde socialbidrag under hög arbetslöshet medan färre människor med fler eller tyngre problem behövde socialbidrag under låg arbetslöshet. En oroande trend idag är att högkonjunktur och ökat utbud av arbeten inte tycks "suga upp» socialbidragstagare i samma omfattning som tidigare (Salonen 2000, Bergman \& Bäckman 2004, 2007, Socialstyrelsen 2006). En anledning som framhålls är att andelen okvalificerade arbeten på arbetsmarknaden kontinuerligt minskar (Esping-Andersen 1996, le Grand et al. 2001, Brulin \& Bäckström 2006). Socialbidragstagare med sin relativt sett låga utbildning och svaga förankring på arbetsmarknaden (Socialstyrelsen 1999, 2005, 2006, Halleröd 2003) riskerar att bli ett slags arbetsöverskott på dagens arbetsmarknad. Ett förhållande som historiskt sett har inneburit att resursdimensionen varit uttalad i socialpolitiken. Lägst chanser till återetablering efter 90-talets krisår har ensamstående män, ensamstående kvinnor med barn, invandrare och ungdomar (Socialstyrelsen 2006, SOU 2007:2, Bergmark \& Bäckman 2007). Hur bedömer socialarbetare försörjningshinder hos dessa grupper?

\section{Data}

Artikeln baseras på material från en studie om arbetssätt i socialbidragsärenden som genomfördes under åren 2002-2004 (Nybom et al. 2005). Fyra kommuner, Karlstad, Norrköping, Upplands Väsby och Östhammar ingick i studien. Till studien valdes 568 ärenden slumpmässigt ut från listor med inbokade besök på respektive kommuns socialkontor. ${ }^{1}$ Vid de valda besöken fanns forskare/forskningsassistenter på plats och frågade klient och socialarbetare om de ville delta i studien. Tio procent av klienterna och ingen av socialarbetarna avböjde medverkan i studien. Klienterna och socialarbetarna intervjuades med enkät, var för sig, om klientens levnadsförhållanden och den aktuella ansökan i samband med detta besök. Cirka ett år senare intervjuades aktuell socialarbetare i samtliga ärenden, bland annat om klientens försörjningshinder.

1 I Norrköping studerades klienter vid ett av fyra kontor. Kontoret arbetade endast med personer över 25 år. 
Socialarbetarnas bedömningar undersöks för klienter där det kan antas att socialtjänsten bedömer klientens försörjningshinder. Det innebär att klienter för vilka socialbidraget är en ersättning för eller komplettering till sjukersättning/sjukpension eller ålderspension uteslöts från det ursprungliga urvalet. När det gäller vilken omfattning på bidragsbehovet klienterna skulle ha för att inkluderas i analysen bedömdes den ofta förekommande kategorin långvariga med socialbidrag tio månader under ett år (se t. ex. Jonasson 1996, Socialstyrelsen 1999, 2006) som alltför snäv. Det förekommer att personer har haft återkommande behov under flera år men ändå inte tio av tolv månader under samma år varför exempelvis Salonen (1994) räknar personer med socialbidrag en fjärdedel av samtliga månader under en femårsperiod till permanenta bidragstagare. Enligt Bergmark och Bäckmans $(2007,2008)$ analyser av socialbidragstagandets varaktighets- och utträdesmönster ökar sannolikheten att ha ett långvarigt bidragsbehov vid bidragsperioder på sex månader. I artikeln analyseras bedömningar för klienter som ansökt om socialbidrag minst sex månader under en tvåårsperiod innan den första intervjun. Med denna avgränsning ingår 372 av studiens ursprungliga 568 klienter i analyserna.

\section{Metod}

Försörjningshinder undersöktes genom att socialarbetarna i uppföljningsintervjun tillfrågades: Har klienten några svårigheter eller hinder att få eller behålla ett arbete? Om så var fallet följde en fråga om vilka hinder som fanns för klienten. Socialarbetarna fick ta ställning till 17 svarsalternativ som beskrev olika försöriningshinder och det var möjligt att välja flera alternativ för varje klient. I bearbetningen skapades följande kategorier:

\section{- Bristande motivation}

- Missbruk (långvarigt missbruk, periodvis missbruk, pågående missbruk)

- Bristande självförtroende

- Trasslig uppväxt

- Ej diagnostiserad ohälsa (ej diagnostiserad sjukdom/psykiska problem/mår dåligt)

- Bristande arbetslivserfarenhet (saknar arbetslivserfarenhet, saknar arbetslivserfarenhet i Sverige)

- Bristande utbildning (saknar skolutbildning, saknar yrkesutbildning, har en av arbetsmarknaden ej efterfrågad utbildning)

- Språksvårigheter

- Diagnostiserad ohälsa (diagnostiserad fysisk sjukdom/funktionshinder, diagnostiserad psykisk sjukdom/funktionshinder)

- Högålder

- Svår arbetsmarknad

Försörjningshindren relateras till moral, resurs och marknad på följande sätt. Till moraldimensionen hör försörjningshinder som förlägger ansvaret för bidragsbehovet på individen. Bristande motivation är det försörjningshinder som tydligast ifrågasätter klientens vilja att arbeta och det representerar därmed den moraliska dimensionen. Att en person missbrukar har historiskt sett liksom idag förknippats med 
ett moraliserande omdöme som betonar individens egen förskyllan till hjälpbehov (se t. ex. Bergmark 1991, Byberg 2002). I en aktuell studie reflekterade socialarbetare, i fokusgruppsintervjuer, över hur de skulle handla i ett fiktivt fall med en socialbidragsklient som visar tecken på alkoholmissbruk (Skogens 2007). Enligt resultaten lade socialarbetarna få moraliska aspekter på missbruket i sig även om det sågs som viktigt att missbruket inte fick gå ut över förmågan att försörja sig själv. Missbruk placeras därför med ett frågetecken i den moraliska dimensionen.

För många försörjningshinder är det en öppen fråga om de skall kopplas till moral eller resurs vilket markeras genom att en dimension kallas moral/resursdimensionen. När det gäller ej diagnostiserad ohälsa kan Bergmarks (1991) resonemang om hur socialarbetare "utifrain deras höga beredskap att 'psykologisera' och diagnostisera beteenden, /.../ beskriver reaktioner som $i$ andra sammanhang skulle framstå som normala eller adekvata i en utsatt situation, itermer av 'psykiska problem' ", illustrera varför detta försörjningshinder tillsammans med bristande självförtroende får representera en moral/ resursdimension. Bristande självförtroende kan också vara ett resultat av den utsatta situationen som bidragstagare. Försörjningshindret trasslig uppväxt får representera moral/resursdimensionen främst för att det inte kan räknas som en legitim resursbrist, vilket kännetecknar resursdimensionen.

Till resursdimensionen hör försörjningshinder som hög ålder, språksvårigheter, diagnostiserad ohälsa, bristande arbetslivserfarenhet och bristande utbildning. Vad som är legitima resursbrister avgörs som nämnts tidigare till stor del av marknadens krav. Bristande arbetslivserfarenhet och utbildning liksom språksvårigheter kan betraktas som legitima resursproblem med tanke på arbetsmarknadens ökade krav på kompetens (SOU 2007:2). Diagnostiserad ohälsa och hög ålder har historiskt sett ofta utgjort accepterade skäl att inte kunna arbeta.

Marknadsdimensionen representeras av svarsalternativet svår arbetsmarknad. Socialarbetarna som väljer detta antas beakta strukturella orsaker till sin klients situation vilket i sin tur ligger nära uppfattningen att samhället har ansvar för utbudet av arbeten vilket kännetecknade marknadsdimensionen.

En svaghet är att marknadsdimensionen endast representeras av ett svarsalternativ medan moral- och moral/resursdimensionen tillsammans samt resursdimensionen representerades av fem svarsalternativ vardera.

\section{Tabell I.}

Bakgrundsegenskaper hos klienterna i studien. Andel i procent. $n=372$

\begin{tabular}{l|c}
\hline Klientegenskaper & $\begin{array}{c}\text { Pro- } \\
\text { cent }\end{array}$ \\
\hline Män & 50 \\
Kvinnor & 49 \\
Födda i Sverige & 54 \\
Utrikes födda & 46 \\
\hline Sammanboende utan barn & 26 \\
(inkl ungdomar som bor hemma) & 12 \\
Sammanboende m barn & 36 \\
\hline Ensamstående utan barn & 26 \\
\hline Ensamstående m barn & 74 \\
\hline Klienter över 25 år & 26 \\
\hline Klienter under 25 år &
\end{tabular}


Socialarbetarnas bedömningar undersöks för klienter med olika kön, ålder, födelseland och typer av hushåll. Detta för att få en bild av om socialarbetarnas bedömningar skiljer sig år systematiskt för de klientgrupper som ofta urskiljs i socialbidragsforskningen, det vill säga ensamstående män, ensamstående kvinnor med barn, ungdomar och utrikes födda (se t. ex. Salonen 2000, Swärd 2000, Franzén 2002, Bergmark \& Palme 2003, SOU 2007:2, Socialstyrelsen 2006). Av Tabell 1 framgår hur dessa egenskaper fördelar sig i den undersökta gruppen.

\section{Resultat}

\section{Försörjningshinder och dimensioner $i$ bedömningen av samtliga klienter}

Vilka försörjningshinder har klienterna enligt socialarbetarna? ${ }^{2}$ Av figur 1 framgår

2 För 48 klienter uppgav handläggarna att klienten inte hade några försörjningshinder och för åtta att de inte visste. Detta var lika vanligt för klienter med olika kön, ålder, födelseland och hushållssituation (ej i Tabell).

\section{Figur I.}

Socialarbetares bedömning av sina klienters försörjningshinder. Flera försörjningshinder fick anges. Siffrorna i figuren anger andel av samtliga klienter som uppgavs ha respektive försörjningshinder. $n=372$.

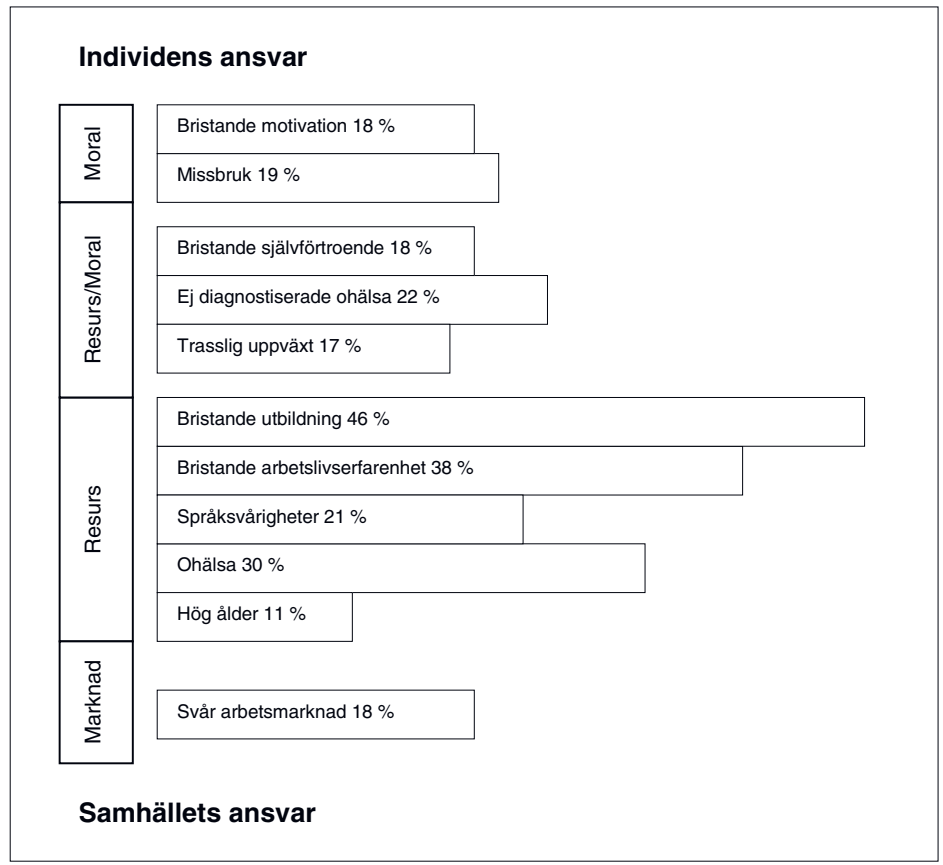

Jenny Nybom: Hur bedömer socialarbetare.. 
socialarbetarnas uppfattningar om försörjningshinder för hela gruppen socialbidragstagare.

Försörjningshinder som har att göra med klienternas resurser, resursdimensionen, är de vanligaste enligt socialarbetarna. För nära hälften av klienterna betraktas bristande utbildning som ett försörjningshinder. För något färre tas bristande arbetslivserfarenhet upp. För en tredjedel av klienterna ses diagnostiserad fysisk eller psykisk ohälsa som ett försörjningshinder. Hög ålder är enligt socialarbetarna ett försörjningshinder för få klienter. Samtliga försörjningshinder i moral eller resurs/moraldimensionen tas upp för cirka en femtedel av klienterna.

Svår arbetsmarknad utgör ett försörjningshinder för en femtedel av klienterna. Med tanke på utvecklingen på arbetsmarknaden som beskrevs inledningsvis kan det tyckas anmärkningsvärt att så få av socialarbetarna väljer ett försörjningshinder med koppling till strukturella villkor. I andra studier där socialarbetare tillfrågats om socialbidragstagande $i$ allmänhet anser en majoritet att strukturella villkor är huvudorsak till klienternas situation (se t. ex. Pettersson 1986, Blomberg et al. 2006). Här mättes vilken betydelse socialarbetare tillmäter strukturella villkor för enskilda klienter. Kanske förde frågans individinriktade formulering om »klientens svårigheter att få arbete« socialarbetarnas uppmärksamhet till klienten och bort från strukturella villkor?

\section{Försörjningshinder och dimensioner $i$ bedömningen av olika klientgrupper}

Hur uppfattar socialarbetarna försörjningshinder hos klienter med olika ålder, kön, födelseland och hushåll? Av Tabell 2 framgår att några skillnader i socialarbetarnas uppfattningar tycks systematisk kopplade till vissa klientegenskaper.

Det gäller dock inte betydelsen av kön som inleder tabellen. Endast ifråga om missbruk skiljer sig socialarbetarnas uppfattningar signifikant åt för kvinnor och män, en skillnad som framkommit i tidigare studier (se t. ex. Jonasson 1996, Stranz 2002).

När det gäller betydelsen av klientens ålder skiljer sig socialarbetarnas uppfattningar signifikant åt mellan ungdomar och vuxna (över respektive under 25 år) för samtliga försörjningshinder utom svår arbetsmarknad. Tre försörjningshinder, språksvårigheter, diagnostiserad ohälsa och missbruk (och självklart hög ålder), tas upp oftare för vuxna än för klienter under 25 år. Inom resursdimensionen tas bristande utbildning och arbetslivserfarenhet upp oftare för ungdomar. Inom moral- och moral/resursdimensionen uppfattar socialarbetarna att ungdomar har bristande motivation, bristande självförtroende, ej diagnostiserad ohälsa och trasslig uppväxt oftare än de vuxna klienterna. Unga bidragstagare uppfattas alltså både ha fler olika slags försörjningshinder och oftare ha försörjningshinder inom moral-som moral/ resursdimensionen än vuxna.

Enligt socialarbetarna är brist på arbetslivserfarenhet och hög ålder (och naturligt 
nog språkproblem) oftare ett försörjningshinder för klienter födda utrikes än för klienter födda i Sverige. Intressant nog upp- fattas bristande utbildning som lika vanligt hos klienter födda i Sverige och utrikes. En tydlig skillnad finns däremot när det gäller

\section{Tabell 2.}

Socialarbetares bedömning av sina klienters försörjningshinder uppdelat på klientens kön, ålder, födelseland och hushållstyp. Flera försörjningshinder fick anges. Andel av samtliga klienter $n=372$. e.s $=$ ej signifikant

\begin{tabular}{|c|c|c|c|c|c|c|c|c|c|c|c|c|c|c|}
\hline $\begin{array}{l}\text { Försörj- } \\
\text { ningshinder }\end{array}$ & $\frac{\Sigma}{\Sigma}$ & 吝 & 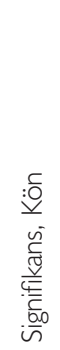 & 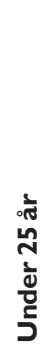 & 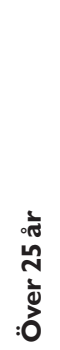 & 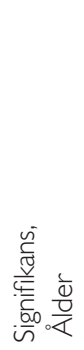 & 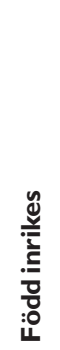 & 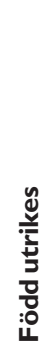 & 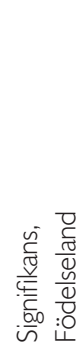 & 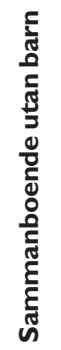 & 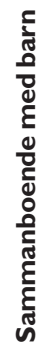 & 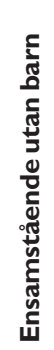 & 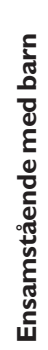 & 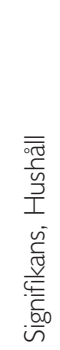 \\
\hline $\begin{array}{l}\text { Bristande } \\
\text { motivation }\end{array}$ & 19 & 16 & e.s & 24 & 15 & $\begin{array}{c}* \\
.042\end{array}$ & 18 & 17 & e.s & 32 & 20 & 11 & 12 & .000 \\
\hline Missbruk & 28 & 9 & 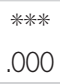 & 12 & 21 & $\begin{array}{l}(+) \\
.052\end{array}$ & 28 & 8 & $\begin{array}{l}* * * * * 1 \\
.000\end{array}$ & 25 & 4 & 24 & 11 & $\begin{array}{l}* * * * * * \\
.002\end{array}$ \\
\hline $\begin{array}{l}\text { Bristande } \\
\text { självförtro- } \\
\text { ende }\end{array}$ & 17 & 18 & e.s & 31 & 13 & $\begin{array}{l}* * * * * \\
.000\end{array}$ & 26 & 8 & $\begin{array}{l}* * * * * 1 \\
.000\end{array}$ & 23 & 2 & 18 & 20 & $\begin{array}{l}* * * \\
.023\end{array}$ \\
\hline $\begin{array}{l}\text { Ej diagnosti- } \\
\text { serad ohälsa }\end{array}$ & 19 & 24 & e.s & 28 & 19 & $\begin{array}{l}(+) \\
.090\end{array}$ & 25 & 18 & e.s & 25 & 20 & 21 & 20 & e.s \\
\hline $\begin{array}{l}\text { Trasslig } \\
\text { uppväxt }\end{array}$ & 16 & 18 & e.s & 39 & 9 & $\begin{array}{l}* * * * * \\
.000\end{array}$ & 23 & 9 & $\begin{array}{l}* * * * * \\
.000\end{array}$ & 24 & 4 & 15 & 17 & $\begin{array}{l}* * * \\
.028\end{array}$ \\
\hline $\begin{array}{l}\text { Bristande } \\
\text { arbetslivs- } \\
\text { erfarenhet }\end{array}$ & 36 & 40 & e.s & 50 & 34 & $\begin{array}{l}* * * * * \\
, 005\end{array}$ & 30 & 48 & $\begin{array}{l}* * * * * \\
, 000\end{array}$ & 50 & 51 & 27 & 36 & $\begin{array}{l}\text { ******* } \\
.002\end{array}$ \\
\hline $\begin{array}{l}\text { Bristande } \\
\text { utbildning }\end{array}$ & 44 & 48 & e.s & 62 & 41 & $\begin{array}{l}* * * * * 1 \\
.000\end{array}$ & 45 & 48 & e.s & 58 & 44 & 37 & 49 & $\begin{array}{l}* * * \\
.018\end{array}$ \\
\hline $\begin{array}{l}\text { Språksvårig- } \\
\text { heter }\end{array}$ & 17 & 24 & e.s & 10 & 25 & $\begin{array}{l}* * * * * 1 \\
.000\end{array}$ & 0 & 46 & $\begin{array}{l}* * * * * 1 \\
.000\end{array}$ & 24 & 44 & 11 & 21 & $\begin{array}{l}\text { ****** } \\
.000\end{array}$ \\
\hline $\begin{array}{l}\text { Diagnosti- } \\
\text { serad } \\
\text { ohälsa }\end{array}$ & 30 & 31 & e.s & 19 & 34 & $\begin{array}{l}\text { ******* } \\
.006\end{array}$ & 31 & 30 & e.s & 30 & 33 & 30 & 31 & e.s \\
\hline Hög ålder & 8 & 14 & e.s & 0 & 15 & $\begin{array}{l}\text { ******* } \\
.000\end{array}$ & 7 & 14 & $\begin{array}{l}\text { **** } \\
.014\end{array}$ & 8 & 11 & 14 & 9 & e.s \\
\hline $\begin{array}{l}\text { Svår arbets- } \\
\text { marknad }\end{array}$ & 17 & 20 & e.s & 18 & 18 & e.s & 16 & 20 & e.s & 22 & 21 & 13 & 22 & e.s \\
\hline
\end{tabular}

${ }^{* * *}=0.001,{ }^{* *}=0,01,{ }^{*}=0,05,(+)=0,1$

Jenny Nybom: Hur bedömer socialarbetare... 
trasslig uppväxt, bristande självförtroende och missbruk, som oftare tas upp för klienter födda i Sverige. I socialarbetarnas bedömningar är alltså försörjningshinder inom resursdimensionen vanligare för utrikes födda medan försörjningshinder inom moral- och moral/resursdimensionen förekommer oftare för klienter födda i Sverige.

Skillnader i uppfattningar om försörjningshinder utifrån klienternas hushållssituation beror i flera fall på att kön, födelseland och ålder korrelerar högt med vissa slags hushåll (ej i Tabell). Till exempel består sammanboende utan barn till hälften av ungdomar (47 \%) vilket innebär att bristande utbildning, bristande arbetslivserfarenhet och bristande motivation är särskilt vanligt för personer från dessa hushåll. Sammanboende med barn består till 87 procent av utrikes födda varför språkproblem är signifikant vanligare i denna grupp. Försörjningshinder i den moraliska dimensionen är mindre vanliga för sammanboende med barn av samma skäl. Man kan notera att klienter som är ensamstående utan barn, varav mer än två tredjedelar är män (70 \%), inte har något försörjningshinder signifikant oftare än klienter från andra hushåll. De missbrukande männen verkar alltså finnas såväl bland de något äldre ensamstående männen som bland yngre sammanboende män utan barn. Ett annat resultat är att gruppen ensamstående med barn, till nära 90 procent (86 \%) kvinnor, endast utmärks av att de mer sällan än andra har bristande arbetslivserfarenhet. Svår arbetsmarknad, marknadsdimensionen, framhålls inte för någon särskild klientgrupp. En möjlig tolkning är att samhällets ansvar betonas av vissa socialarbetare snarare än för vissa klienter. Att analysera det faller dock utanför ramen för artikeln.

Ensamstående kvinnor med barn är en utsatt grupp, deras bidragstagande är det högsta i relation till gruppens andel i befolkningen (se t. ex. Salonen 2000). Till skillnad från andra bidragsgrupper är det inget försörjningshinder som socialarbetarna tar upp särskilt ofta för den här gruppen. Enkätfrågan om försörjningshinder hade fasta svarsalternativ vilket innebär en risk att försörjningshinder som socialarbetarna uppfattar saknas bland svarsalternativen.

I enkäten ställdes en öppen fråga som löd: Kan du beskriva den här klienten och dennes problem bakom biståndsbehovet? Även om svaren på denna fråga inte är jämförbara med dem som handlar om försörjningshinder ger de en inblick i socialarbetarnas bild av klienternas situation. Socialarbetarnas uppfattning om vilka slags problem som ligger bakom klienternas biståndsbehov motsvarar kategorierna av försörjningshinder med ett undantag. Familjesituationen beskrevs relativt ofta som ett problem bakom biståndsbehovet. För 40 procent av kvinnorna (och hälften av de ensamstående klienterna med barn varav $86 \%$ är kvinnor) beskrev socialarbetarna olika förhållanden i familjen som problem. Familjesituationen togs endast upp för fyra procent av männen. Beskrivningarna rör oftast barnen, exempelvis att barnen hade problem i skolan eller en sjukdom av något slag. Andra beskrivningar rör skilsmässor, vårdnadstvister och i några fall (kvinno-) misshandel. Så här kunde familjesituationen beskrivas:

"Kvinna med tre små barn. Allvarligt miss- 
handlad av mannen och på grund av detta har hon kommit ner i en svacka"

"Yngre medelailders kvinna med sex barn. Ensamstående. Gör så gott hon kan. Dålig överblick över sitt liv och sin ekonomi" "Lätt klient som hade viljan att fullfölja trots två barn med ADHD«

"Äktenskapsinvandring som resulterade i misshandel och skilsmässa"

Tillhör en svår familjesituation moraleller resursdimensionen i socialarbetares bedömning? Att ha en problematisk familjesituation är inte en fråga om resurser på samma sätt som att sakna utbildning eller språkkunskaper. Tengvald (1976) tydliggjorde för några decennier sedan att stora utgifter var en viktig utlösande faktor bakom socialbidragsbehov medan tidigare forskning främst varit inriktad på otillräckliga inkomster. Kanske kan man här dra en parallell till kvinnor och deras familjesituation. För kvinnor och ensamma mödrar kan en hög belastning i form av exempelvis sjuka barn eller en misshandlande make vara betydelsefulla faktorer för försörjningssituationen. Ändå fanns inte familjesituation med som ett valbart svarsalternativ på frågan om försörjningshinder.

\section{Samtidigförekomst av försörjningshinderhos klienterna}

När försörjningshinder inom en dimension tas upp ofta för en klientgrupp betyder det inte med säkerhet att dimensionen har en framträdande roll i bedömningarna av gruppen. För att ta ungdomarna som exempel kan det vara så att det är olika ungdomar som socialarbetarna uppfattar har bristande motivation, bristande självförtroende respektive trasslig uppväxt som försörjningshinder. Om bristande utbildning och arbetslivserfarenhet ofta sammanfaller hos ungdomar medan trasslig uppväxt och ej diagnostiserad ohälsa inte gör det har resursdimensionen samma eller större plats än moraldimensionen i bedömningarna. Genom att undersöka hur olika försörjningshinder korrelerar med varandra prövar vi förra avsnittets resultat, att moral- och moral/resursdimensionen och resursdimensionen hade olika plats $i$ bedömningen av olika klientgrupper. Korrelationskoefficienten Phi kan anta värden mellan 1 och -1. Phi är 0 mellan två försörjningshinder när klienter såväl med som utan det ena försörjningshindret lika ofta har det andra (enligt socialarbetarna).

Som framgår av Tabell 3 är sambanden mestadels relativt svaga. Den högsta korrelationen i matrisen finner vi mellan uppfattningar att en klient har bristande utbildning och samtidigt bristande arbetslivserfarenhet. Enligt socialarbetarna saknar alltså många klienter två av de resurser som är tydligast kopplade till arbetsmarknadens krav.

Bristande motivation i moraldimensionen är korrelerad med samtliga försörjningshinder inom moral/resursdimensionen och med de försörjningshinder inom resursdimensionen som var vanligast hos ungdomar och med marknadsdimensionen genom svår arbetsmarknad. Samtidigt korrelerar samtliga försörjningshindren i moral/resursdimensionen, bristande självförtroende, ej diagnostiserad ohälsa och trasslig uppväxt, med varandra. De är i sin

Jenny Nybom: Hur bedömer socialarbetare... 
tur korrelerade med bristande utbildning, det försörjningshinder som socialarbetarna tog upp för över 60 procent av ungdomarna. Sammantaget tyder korrelationerna på att det relativt ofta är samma ungdomar som uppfattas ha många försörjningshinder samtidigt och flera försörjningshinder i moral- och moral/resursdimensionen sam-

Tabell 3.

Korrelationer (Phi) mellan olika försörjningshinder. Samtliga klienter. $n=372$

\begin{tabular}{|c|c|c|c|c|c|c|c|c|c|c|c|}
\hline $\begin{array}{l}\text { Försörj- } \\
\text { nings- } \\
\text { hinder }\end{array}$ & 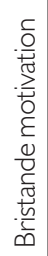 & 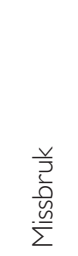 & 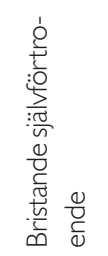 & 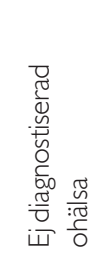 & 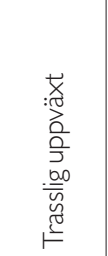 & 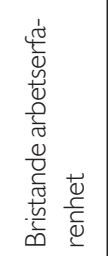 & 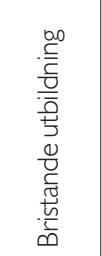 & 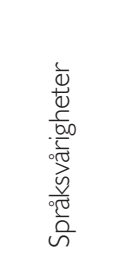 & 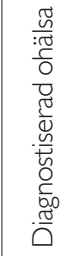 & $\begin{array}{l}\frac{1}{0} \\
\frac{0}{0 \cdot 0} \\
0,0 \\
: 0 \\
\frac{0}{1}\end{array}$ & 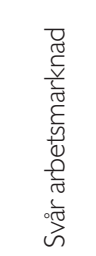 \\
\hline $\begin{array}{l}\text { Bristande } \\
\text { motiva- } \\
\text { tion }\end{array}$ & I & .082 & $.263 * * *$ & $\left..15\right|^{* * *}$ & $.245 * * *$ & $.185 * * *$ & $.162 * * * *$ & .003 & -.016 & -.074 & $.217^{* * * * * *}$ \\
\hline Missbruk & & I & .100 & -.018 & .135 ***. & $-.109 *$ & -.046 & $-.197 * * * *$ & -.079 & .050 & -.032 \\
\hline $\begin{array}{l}\text { Bris- } \\
\text { tande } \\
\text { självför- } \\
\text { troende }\end{array}$ & & & I & $.305 * * * *$ & $.453 * * * *$ & $.170 * * * *$ & $.247 * * * *$ & $-.170 * * * *$ & .045 & -.096 & $.163 * *$ \\
\hline $\begin{array}{l}\text { Ej } \\
\text { diagnos- } \\
\text { tiserad } \\
\text { ohälsa }\end{array}$ & & & & I & $.222 * * * *$ & $.114 *$ & $.118 *$ & .020 & $.110 *$ & .087 & $.159 * *$ \\
\hline $\begin{array}{l}\text { Trasslig } \\
\text { uppväxt }\end{array}$ & & & & & I & $.153 * *$ & $.222 * * * *$ & $-.213 * * *$ & .034 & $-.157 * *$ & .050 \\
\hline $\begin{array}{l}\text { Bristande } \\
\text { arbetslivs- } \\
\text { erfarenhet }\end{array}$ & & & & . & & I & .492 ***** & .316 ***** & .071. & .095 & $.172 * * *$ \\
\hline $\begin{array}{l}\text { Bristande } \\
\text { utbildning }\end{array}$ & & & & & & & I & .145 ** & .056 & .070 &.$|6|$ ****** \\
\hline $\begin{array}{l}\text { Språksvå- } \\
\text { righeter }\end{array}$ & & & & & & & & I & -.091 & .262 ***** & .098 \\
\hline $\begin{array}{l}\text { Diagnos- } \\
\text { tiserad } \\
\text { ohälsa }\end{array}$ & & & & & & & & & I & $.122 *$ & .081 \\
\hline $\begin{array}{l}\text { Hög } \\
\text { ålder }\end{array}$ & & & & & & & & & & I & $.233^{* * * * * *}$ \\
\hline $\begin{array}{l}\text { Svår } \\
\text { arbets- } \\
\text { marknad }\end{array}$ & & & & & & & & & & & I \\
\hline
\end{tabular}

${ }^{* * *}=0.001,{ }^{* *}=0,01,{ }^{*}=0,05$ 
tidigt. Det styrker resultatet att moral- och moral/resursdimensionen är framträdande i bedömningar av ungdomar. Språksvårigheter är negativt korrelerat med trasslig uppväxt, bristande självförtroende och missbruk. Det bekräftar att försörjningshinder i moral- och moral/resursdimensionen sällan tas upp för utrikes födda.

Två försörjningshinder, missbruk och diagnostiserad ohälsa skiljer ut sig från de övriga. De är inte särskilt korrelerade med några andra försörjningshinder. $\mathrm{Om}$ en socialarbetare anser att en klient har missbruksproblem eller sjukdom som försörjningshinder tycks det inte systematiskt påverka deras uppfattningar om andra försörjningshinder hos klienten. Missbruk korrelerar endast (och lågt) med trasslig uppväxt och negativt med språksvårigheter vilket kan förklaras av att utrikes födda sällan uppfattades ha missbruk. Diagnostiserad ohälsa korrelerar endast, och lågt, med ej diagnostiserad ohälsa. Båda dessa försörjningshinder korrelerar lågt med såväl svår arbetsmarknad som bristande motivation. Den svaga korrelationen mellan missbruk och bristande motivation sätter ytterligare frågetecken kring föreställningen att socialtjänsten skulle ha en moraliserande syn på missbruk.

\section{Sammanfattning och diskussion}

Resultaten i den här artikeln har i sammandrag visat:

- Klienternas bristande resurser, och därmed resursdimensionen, är mest framträdande i socialarbetarnas bedömningar sett till hela gruppen bidragstagare. Brist på utbildning är det försörjningshinder som tas upp oftast.

- Ungdomar framstår som tyngst belastade i socialarbetarnas bedömningar Såväl bristande utbildning och arbetslivserfarenhet i resursdimensionen som bristande självförtroende, ej diagnostiserad ohälsa och trasslig uppväxt i moral/ resursdimensionen samt bristande motivation i moraldimensionen uppfattas oftare som försörjningshinder för ungdomar än för övriga klientgrupper.

- Utrikes födda bedöms övervägande ha försörjningshinder inom resursdimensionen t. ex. språksvårigheter och bristande arbetslivserfarenhet.

- Ensamstående kvinnor med barn har inget utmärkande försörjningshinder. Kompletterande analyser visade däremot att en svår familjesituation ofta uppfattades som orsak till deras biståndsbehov av socialarbetarna.

- Klienter med missbruk som försörjningshinder uppfattas inte ha bristande motivation oftare än andra klienter. Missbruk tycks inte vara ett försörjningshinder i moraldimensionen.

En moraliserande syn på hjälpsökande och höga krav på klienten för att bevisa sig arbetsvillig anses gå hand $i$ hand enligt tidigare forskning. I dagens socialpolitik betonas kraven på motprestationer för att få socialbidrag vilket bland forskare har tolkats som att moraldimensionen återinträtt i den institutionaliserade synen på hjälpsökande. Samtidigt tycks socialbidragstagare bli överskottsarbetskraft när fler arbeten 
kräver höga kvalifikationer, något som historiskt sett varit förenat med att resursdimensionen framhållits i socialpolitiska resonemang. Hur kan vi förstå socialarbetarnas bedömningar och dimensionernas plats i dem mot bakgrund av de institutionella och strukturella förhållanden som beskrivits?

En avgörande fråga är hur vi väljer att betrakta moral/resursdimensionen, den dimension som skiljer sig tydligast åt i socialarbetarnas bedömningar av olika klientgrupper. Moral/resursdimensionen omfattar försörjningshinder som trasslig uppväxt, dåligt självförtroende och ej diagnostiserad ohälsa. När socialarbetare tar upp dessa förhållanden som försörjningshinder kan vi välja att se det som att orsakerna till bidragsbehovet förläggs på individen och dennes egenskaper, vilket kännetecknande moraldimensionen. En möjlig slutsats är då att dagens socialpolitiska betoning på hjälpsökandes motprestationer, tydligast adresserad till ungdomar i lagstiftningen, återspeglas genom moraldimensionens framträdande plats i socialarbetares bedömningar av ungdomarna. Enligt denna tolkning återspeglas den institutionaliserade synen på hjälpsökande i socialarbetares syn på sina klienter, deras handlingsutrymme till trots.

Om vi däremot väljer att se normal uppväxt, ett hyggligt självförtroende och frånvaro av diffus ohälsa (att må dåligt utan diagnos) som en slags mjuka resurser (och arbetslivserfarenhet, relevant utbildning, hälsa och adekvata språkkunskaper som hårda resurser), blir slutsatsen en annan. Då kan man istället tolka resultaten som att den krävande arbetsmarknaden med få okvalificerade arbeten och statens mins- kande åtagande (arbetsförmedlingarnas tillbakadragande) har gett resursdimensionen en mycket framträdande plats i socialarbetarnas bedömningar, men, bara för vissa klientgrupper. Denna tolkning innebär att arbetsmarknadens struktur kan ha ett inflytande på socialarbetares bedömningar som är likvärdigt med eller större än socialpolitiska tankegångar, men inte nödvändigtvis på ett likartat sätt för olika klientgrupper.

Sammanfattningsvis varierar socialarbetares bedömningar av försörjningshinder systematiskt med olika klientgrupper. För praktiker kan resultaten förhoppningsvis ses som en uppmuntran att ta bedömningsarbetet på allvar och en utgångspunkt för diskussioner om generaliserande föreställningar om klienters försörjningshinder i det egna arbetet.

En angelägen fråga i ett socialpolitiskt sammanhang är hur generaliserande resonemang kring hjälpsökande på institutionell nivå påverkar bedömningen och hanteringen av deras situation i praktiken.

Resultaten synliggör också nya kunskapsbehov och forskningsfrågor: Hur hänger bedömningar av försörjningshinder och socialtjänstens insatser ihop? Skiljer sig insatser åt för grupper som bedömts ha olika försörjningshinder? Är det vanligare att det ställs krav på motprestationer för klienter med några särskilda försörjningshinder? För att närmare förstå vad de systematiska skillnaderna i socialarbetares bedömningar är uttryck för behövs mer kunskap om socialtjänstens arbete med enskilda socialbidragstagare. 


\section{Referenser}

Ahrne, Göran (1993) Delvis människa, delvis organisation. Stockholm: Stockholms universitet, Sociologiska institutionen.

Bergmark, Åke \& Bäckman, Olof (2008) Socialbidragstagandets mönster - en studie i varaktighet och utträden under 2000-talen. Arbetsrapport 2008:9. Stockholm: Institutet för framtidsstudier.

Bergmark, Åke \& Bäckman, Olof (2007) „Socialbidragstagandets dynamik - varaktighet och utträden från socialbidragstagande under 2000-talet." Socialvetenskaplig tidskrift nr 14 (2-3), s. 134-152.

Bergmark, Åke \& Bäckman, Olof (2004) „Stuck with Welfare? Long-term Social Assistance Recipiency in Sweden." European Sociological Reviewnr 20, pp. 425-443.

Bergmark, Åke \& Palme, Joakim (2003) „Welfare and the unemployment crisis: Sweden in the 1990s." International Journal of Social Welfare nr 12, pp. 108-122.

Bergmark, Åke (1993) „Den värdiga hjälptagaren i historisk belysning." I De ekonomiska trygghetssystemen-i ett historiskt och internationellt perspektiv. FKF Fakta. Stockholm: Försäkringskasseförbundet.

Bergmark, Åke (1991) Socialbidrag och försörjning. En studie av bidragstagande bland ensamstående män utan barn. Rapport i socialt arbete nr 55. Stockholm: Stockholms universitet, institutionen för socialt arbete. (akademisk avhandling)

Billquist, Leila (1999) Rummet, mötet, ritualerna. En studie av socialbyrån, klientarbetet och klientskapet. Skriftserien 1999:4. Göteborg: Göteborgs universitet, institutionen för socialt arbete. (akademisk avhandling)

Blomberg Gustaf, Ekström Veronica \& Rauhut Daniel (2006) Bidrag och motprestation - en uppföljning av arbetet med arbetslösa socialbidragstagare i sex stadsdelsområden i Stockholms stad. FoU-rapport 2006:12. Stockholm: Stockholm Stad.

Brulin, Göran \& Bäckström, Henrik (2006) »En svensk arbetslinje för det tjugoförsta seklet?» Sociologisk forskning $\mathrm{nr}$ 2, s. 97-128.

Byberg, Ingrid (2002) Kontroll eller handlingsfrihet? - en studie av organiseringens betydelse $i$ socialt arbete. Rapport i socialt arbete nr 101. Stockholm: Stockholms universitet, institutionen för socialt arbete. (akademisk avhandling)

Esping-Andersen, G (ed.) (1996) Welfare State in Transition. National Adaptions in Global Economies. Wiltshire: Sage.

Franzén, Eva (2003) I välfärdsstatens väntrum. Studier av invandrares socialbidragstagande. Skriftserien 2006: 2. Göteborg: Göteborgs universitet, institutionen för socialt arbete. (akademisk avhandling)

Giertz, Anders (2004) Making the Poor Work. Social Assistance and Activation Programs in Sweden. Dissertations in Social Work 19. Lund: Lunds universitet, Socialhögskolan. (akademisk avhandling)

Gunnarsson, Evy (1993) I välfärdsstatens utmarker: om socialbidrag och försörjning bland ensamstående kvinnor utan barn. Rapport i socialt arbete nr 64. Stockholm: Stockholms universitet, institutionen för socialt arbete. (akademisk avhandling)

Gustafsson Björn, Hydén Lars-Christer \& Salonen Tapio (1990) Beslut om socialbidrag i storstäder. Sekr. för sociala studier 1990:4. Malmö: Malmö socialförvaltning.

Halleröd, Björn (2003) „Varför får folk socialbidrag? Analys av socialbidragstagandets bestämningsfaktorer." Socialvetenskaplig tidskrift $\mathrm{nr}$ 10 (2-3), s. 238-266.

Hedblom, Agneta (2004) Aktiveringspolitikens janusansikte. En studie av differentiering, inklusion och marginalisering. Dissertations in Social Work 16. Lund: Lunds universitet, Socialhögskolan. (akademisk avhandling)

Hydén, Lars-Christer (1991) Moral och Byråkrati. Om socialbidragsansökningar. Stockholm: Stockholms socialförvaltning, Forsknings- och utvecklingsbyrån.

Hydén Lars-Christer, Khyle Westermark Pia \&

Jenny Nybom: Hur bedömer socialarbetare... 
Stenberg Sten-Åke (1995) Att besluta om socialbidrag, en studie i 11 kommuner. CUS-skrift 1995:1. Stockholm: Socialstyrelsen.

Johansson, Roine (1992) Vid byråkratins gränser: om handlingsfrihetens organisatoriska begränsningar $i$ klientrelaterat arbete. Lund: Arkiv förlag.

Johansson, Håkan (2001) I det sociala medborgarskapets skugga. Rätten till socialbidrag under 1980- och 1990- talen. Arkiv avhandlingsserie 55. Kungälv: Arkiv förlag. (akademisk avhandling)

Jonasson, Ingrid (1996) Långvariga socialbidragstagare. Rapport i socialt arbete nr 80. Stockholm: Stockholms universitet, institutet för socialt arbete. (akademisk avhandling)

Junestav, Malin (2004) Arbetslinjer i svensk socialpolitisk debatt och lagstiftning 1930 -2001. Uppsala: Uppsala universitet, Ekonomisk-historiska institutionen. (akademisk avhandling)

Kullberg, Christian (1994) Socialt arbete som kom munikativ praktik. Samtal med och om klienter. SIC 115. Linköping: Linköpings universitet, Tema kommunikation. (akademisk avhandling)

le Grand Carl, Szulkin Ryzard \& Tåhlin Michael (2001) "Har jobben blivit bättre?» I Johan Fritzell, Michael Gähler \& Olle Lundberg (red.) Välfärd och arbete $i$ arbetslöshetens årtionde. SOU 2001:53. Kommittén Välfärdsbokslut. Stockholm: Fritzes.

Lindqvist, Rafael \& Marklund, Staffan (1995) "Forced to work and deliberated from work. A historical perspective on work and welfare in Sweden." Scandinavian Journal of Social Welfarenr 4, s. 224-237.

Lipsky, Michael (1980) Street-level bureaucracy. Dilemmas of the Individual in Public Service. New York: Russell Sage Foundation.

Lødemel, Ivar \& Trickey, Heather (eds.) (2001) An offer you can't refuse. Workfare in an international perspective. Southampton: The Policy Press.

Midré, Georges (1990) Bøt, bedring eller brød? Om bedømming og behandling av sosial nød fra reformasionen til folketrygden. Oslo: Universitetsforlaget.

Nybom Jenny (red.), Puide Annika, Roselius Maria
\& Hjulström Fredrik (2005) Förutsättningar för socialbidragsarbete - en jämförelse av fyra kommuner. Stockholm: Socialstyrelsen.

Pettersson, Ulla (1986) Socialtjänsten i praktiken. Från mål till verklighet. Angered: Skeab förlag.

Prottas, Jeffrey Manditch (1979) People-Processing. Toronto: Lexington Books.

Salonen, Tapio (1994). Välfärdens marginaler. Stockholm: Publica.

Salonen, Tapio (2000) "Hundra år av understöd». I Annika Puide (red.) Socialbidrag i forskning och praktik. Stockholm: Gothia.

Salonen, Tapio \& Ulmestig, Rickard (2004) Nedersta trappsteget. En studie om kommunal aktivering. Växjö: Växjö universitet, institutionen för vårdvetenskap och socialt arbete.

Skogens, Lisa (2007) Hur bedöms manliga socialbidragstagare med alkoholproblem? Regler, kunskap och kontext $i$ socialt arbete. Rapport i socialt arbete nr 124. Sockholm: Stockholms universitet, institutionen för socialt arbete. (akademisk avhandling)

Socialstyrelsen (1999) Långvarigt socialbidragsberoende under 1990-talet. Socialstyrelsen följer upp och utvärderar 1999:5. Stockholm: Socialstyrelsen.

Socialstyrelsen (2004) Systematisk bedömning inom socialtjänsten. Stockholm: Socialstyrelsen.

Socialstyrelsen (2005) Jämställd socialtjänst. Stockholm: Socialstyrelsen.

Socialstyrelsen (2006) Social rapport 2006. Stockholm: Socialstyrelsen.

SOU 2000:3. Välfärd vid vägskäl. Utvecklingen under 1990-talet. Delbetänkande från Kommittén Välfärdsbokslut. Stockholm: Fritzes.

SOU 2007:2. Från socialbidrag till arbete. Stockholm: Fritzes

Stranz, Hugo (2007) Utrymme för variation. Rapport i socialt arbete nr 119. Stockholm: Stockholms universitet, institutionen för socialt arbete. (akademisk avhandling)

Stranz, Hugo (2002) Långvariga socialbidragstagare - en studie i två kommuner. Stockholm: Svenska Kommunförbundet.

Swärd, Hans (2000) „Ungdomar med socialbidrag». 
I Annika Puide (red.) Socialbidrag i forskning och praktik. Stockholm: Gothia.

Tengvald, Karin (1976) Samhällets krav och de fattigas resurser: en begreppsram för studiet av nyfattigdom i storstadsområden med en sammanfattning av två empiriska undersökningar. Uppsala: Uppsala universitet, Sociologiska institutionen. (akademisk avhandling)

Thorén, Katarina H (2005) Kommunal aktiveringspolitik: en fallstudie av det praktiska arbetet med arbetslösa socialbidragstagare. IFAU Rap- port 2005:11. Uppsala: Institutet för arbetsmarknadspolitisk utvärdering.

Ulmestig, Rickard (2007) På gränsen till fattigvård? En studie om arbetsmarknadspolitik och socialbidrag. Dissertations in Social Work 27. Lund: Lunds universitet: Socialhögskolan. (akademisk avhandling)

Wallentin, Hans (1999) „Värdiga och ovärdiga i socialpolitiken." I Alf Ronnby (red.) Etik och idéhistoria $i$ socialt arbete. Stockholm: Socionomen.

\section{Summary}

\section{Social workers' assessments of welfare recipients' barriers to work}

In Sweden, assessments of social assistance recipients are in general examined as the question of whether claimants are entitled to money, and if so how much and how this may vary. Nordic studies of the social service institution through time show that the question of barriers and ability to work has been crucial in handling entitled claimants. In the article the institutionalized view of people in need, i.e. the view in social policy laws and documents, is used to analyse social workers' assessment of their clients' barriers to work. The institutionalized view of people in need includes three dimensions: the clients' morals (willingness to work), the clients' resources (capacity to work) and the role of the market (society's responsibility to make it possible for people find work). Research shows that these dimensions are given varying attention across time and in different structural conditions.

Survey data from social workers concerning 372 recipients from four municipali- ties was analysed. The question asked was: Does the client have any barriers to getting a job or to keeping a job? If that is the case - what are the barriers? The social workers were asked to choose an optional number of seventeen possible barriers to work for each client.

The overall results show that the resource dimension is dominant in the social workers' assessment of the clients as a whole group. Lack of education is the barrier mentioned most frequently ( $46 \%$ of the clients). Barriers connected to morale and the market dimensions were mentioned to the same extent. Moreover, the social workers' assessments vary systematically with age and ethnicity. Barriers potentially related to the moral dimensions, such as lack of motivation, lack of self-confidence or a difficult childhood are brought up noticeably more often for young people (under 25). For immigrants these barriers are rarely mentioned. 